JOURNAL OF THE SOUTH AFRICAN INSTITUTION OF CIVIL ENGINEERING ISSN 1021-2019

Vol 62 No 1, March 2020, Pages 22-32, Paper 0837

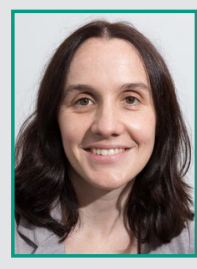

NANINE FOUCHÉ graduated in 2008 with a Bachelor's degree in Earth Science from Stellenbosch University. Thereafter she continued her studies and completed a Post-Graduate Diploma and an MSC Eng in Geotechnical Engineering. She gained valuable experience as an engineering geologist at Aurecon South Africa, undertaking geotechnical and foundation investigations for a wide range of projects. Her passion for teaching and the academics led her to a career in teaching and research in the Civil Engineering Department of Stellenbosch University. She currently teaches geotechnical engineering courses and provides support to geotechnical research students, while also completing her PhD.

Contact details:

Department of Civil Engineering

Stellenbosch University

Private Bag X1

Matieland 7602

South Africa

T: +27218083816

E: naninef@sun.ac.za

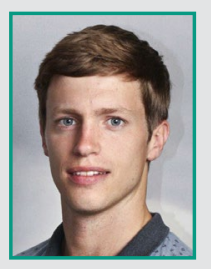

JOHAN BLIGNAUT is a Junior Mine Seismologist at the Insitute of Mine Seismology, Stellenbosch. He received his Master's Degree in Geotechnical Engineeering at the University of Stellenbosch in March 2019 after completing a Bachelor's Degree with Honours in Earth Science at the same university. At the Institute of Mine Seismology he is part of a team that utilises newly developed techniques in seismic noise interferometry for tomography and monitoring applications in the mining environment.

Contact details:

Postgraduate Student

Department of Civil Engineering

Stellenbosch University

Private Bag X1

Matieland 7602

South Africa

T: +27783962655

E: joe07839@gmail.com

\title{
A preliminary study of the engineering properties of dorbank
}

\author{
N Fouché, J Blignaut
}

Dorbank, a naturally indurated, pedogenic layer, is found over vast expanses of arid and semi-arid parts of southern Africa. Although considered a nuisance to local farmers, dorbank is relatively easy to rip from the soil profile to clear the way for agricultural developments. Its strategic position just beneath the topsoil in the soil profile, as well as its consistency which is often close to that of rock, raises the question of its engineering capabilities. In this study the properties of unbound, mechanically crushed dorbank gravels were investigated in the context of exploiting dorbank for road-building purposes. Moreover, the study investigated the pedogenic variance of dorbank for possible indicators of engineering quality. Dorbank samples were taken from three different regions in the Karoo - the vicinity of Vanrhynsdorp, Aggeneys and the Vaalputs radioactive waste disposal facility near Springbok. Samples were subjected to two stages of investigation.

Firstly, the pedogenic nature of dorbank was determined. Different morphologies of dorbank and their relation to the soil type in which they were found were described, whereafter cementing agents were selectively dissolved from dorbank while noting the resulting effect on its structural strength. Polished dorbank sections were additionally analysed with scanning electron microscopy (SEM), coupled with energy-dispersive x-ray (EDX) spectroscopy to identify minerals that are deleterious to roadworks and to understand the chemical enrichment of dorbank by cementing agents.

Secondly, the unbound granular qualities of dorbank were tested to establish its use as a material in the structure of a flexible pavement or as a gravel wearing coarse. Dorbank samples were crushed with a small jaw crusher from which the particle size distribution (PSD), the flakiness index (FI), pH, electrical conductivity (EC), Atterberg limits, linear shrinkage (LS), maximum dry density (MDD), optimum moisture content (OMC), soaked California Bearing Ratio (CBR) and direct shear strength (DST) of remoulded samples were determined. The strength and durability of particles that fell within the 13.2 to $19.0 \mathrm{~mm}$ size fraction were evaluated with the Treton impact test, the aggregate pliers test (APT) and the accelerated weathering test (AWT).

Dorbank samples presented as platy and as massive morphologies in transported sandy soils. Platy dorbanks were found to occur in silty sands, and massive dorbanks in medium to coarse sands. Dorbanks were often found overlying calcrete horizons and containing calcerous veins, which cause adverse discontinuities in the macro- and micro-morphology of dorbank. From the selective dissolution test with $\mathrm{NaOH}$ and $\mathrm{HCl}$, and with quantitative SEM-EDX analyses, samples were confirmed to be petroduric in nature. Dorbank fell short of the South African road-base material requirements, particularly due to its low CBR and low durability. Furthermore, dorbanks were found to be almost cohesionless from the DST results $\left(c^{\prime}=3\right.$ to $\left.7 \mathrm{kN} / \mathrm{m}^{2}\right)$ and non-plastic from the Atterberg limit test results. The aggregate strength and grading coefficient of dorbank from the Vanrhynsdorp and Vaalputs regions satisfy the requirements for use as a gravel wearing coarse, although possible corrugating, ravelling and a high re-gravelling frequency and dustiness can be expected.

Finally, the study concluded that platy dorbank performs better in strength tests, but weather more quickly in the accelerated weathering test. The lack of cohesion and its nonplastic behaviour are likely due to the suppression of the activity of clay, which in turn is due to cementation and the aggregation of clay minerals. Further investigation of dorbank gravels, modified with the addition of fines, is suggested.

\section{INTRODUCTION}

Over vast expanses of the semi-desert landscape of southern Africa a pedocrete soil layer, called dorbank, exists just beneath the topsoil of transported soils. Pedocretes are surficial, authigenic deposits formed either as a weathering residue (laterite), or by the cementation of pre-existing soil, producing a pedological unit with unique properties.

Naturally indurated by silica, calcium carbonates, iron oxides and other chemical 


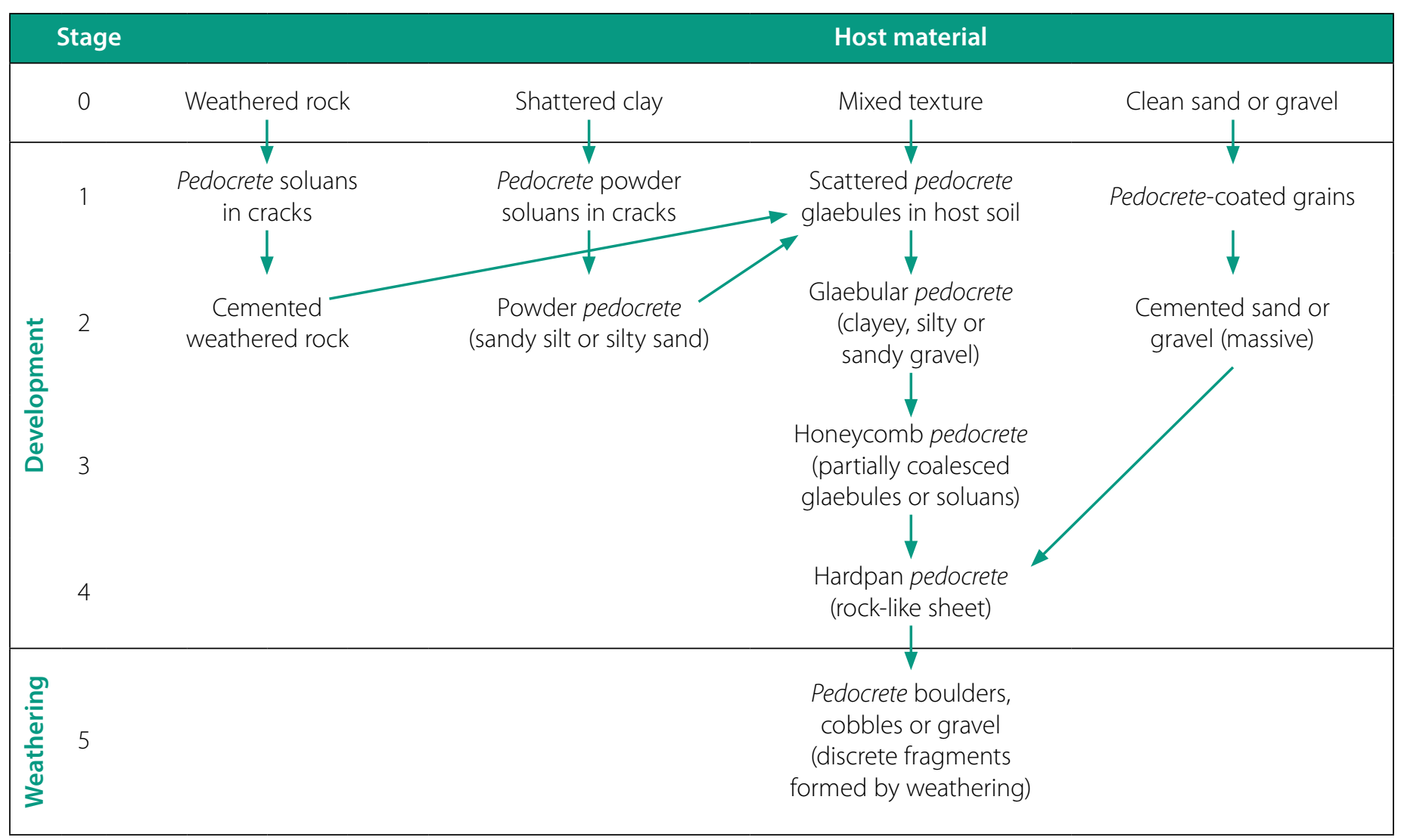

Figure 1 A suggested South African classification system (Brink 1985 modified from Netterberg 1969, 1971); a soluan is defined as soluble fissure filling, and glaebules as nodules or concretions

agents, the consistency of dorbank is often such that it resembles rock. Dorbank occurs over large areas of semi-arid to arid parts of South Africa, mostly in the Northern Cape and to a lesser extent in the Western and Eastern Cape Provinces (Brink 1985). Universally known as duripans, its presence has been noted in many different countries, including Mexico, Peru, Brazil, parts of the USA and Australia. Over the years duripans were included mostly in soil morphology studies and occasionally as founding layers, but for the most part the engineering properties of duripans have been overlooked and their capabilities remain an open discussion.

Cemented predominantly by silica, dorbank is not to be confused with silcrete, which contains more than $50 \%$ silica cement in its matrix and forms under different conditions. In addition to the silica cement, dorbanks may contain up to $15 \%$ clay, with calcium carbonate and iron oxides often occurring as accessory cements. Typically forming distinct horizons of up to $1.2 \mathrm{~m}$ thick, according to Ellis and Schloms (1981), dorbanks have been divided into two main types, namely massive dorbank and platy/laminar dorbank.

Existing academic literature on dorbank appears as trivial parts of larger studies, or as part of engineering case studies
(Brink 1985). The engineering properties of pedocretes depend on three aspects - the texture of the host material, the degree of induration or replacement, and the nature of the cementing or replacing mineral (Brink 1985). For instance, the behaviour of calcerous soils may be analogous to the host material, but indurated calcretes essentially behave in the same way as limestone, and powdery calcrete as chalk (Ismael \& Al-Sanad 1986; Ismael \& Ahmad 1990).

Problems arise when classifying pedocretes in the soil profile according to conventional engineering methods. Treating pedocretes as soils or aggregated materials that can be classified based on particle size distribution and plasticity properties is ambiguous, as these features are reliant on the method of excavation and processing applied (Brink 1985). Whilst many pedocretes exhibit strength properties similar to that of lithified sediments, this is not always true, and the classification of pedocretes in terms of rocks or soil often falls short (Amin et al 2007).

The most comprehensive classification scheme applicable to South Africa, based on extensive research done by Netterberg (1980), captures the important abovementioned controlling traits, by describing the morphology-bearing distinction on the degree of cementation reached (Figure 1).
A range of material properties influences the durability of an unbound gravel or aggregate in the road structure or as a wearing course. The ability of an aggregate skeleton to carry force on inter-particle contacts without chipping or cracking is a good measure of the degree of disintegration (CSRA 1985). The Highway Materials Committee suggests that an unpaved road should be designed bearing in mind that it may form the base of a paved road in the future (CSRA 1990), and more emphasis should certainly be placed on the ability of the wearing course to resist exposure to the elements and weathering by traffic, and should provide sufficient drainage (Netterberg \& Paige-Green 1998).

Dorbank is a recent geological phenomenon, and is currently still forming (Ellis 2002; Frey 2010; Francis et al 2013). Therefore the climatic conditions that it exists in today are likely to also be the conditions in which it will perform best if applied in engineering works. The climatic $\mathrm{N}$-value, developed by Weinert (1980), provides appropriate geographical constraints to the occurrence of different pedocrete types in South Africa (Brink 1985). Figure 2(a) shows platy dorbank.

Although more relevant to surface seals, the resistance to abrasion or polishing might also influence the quality of a 


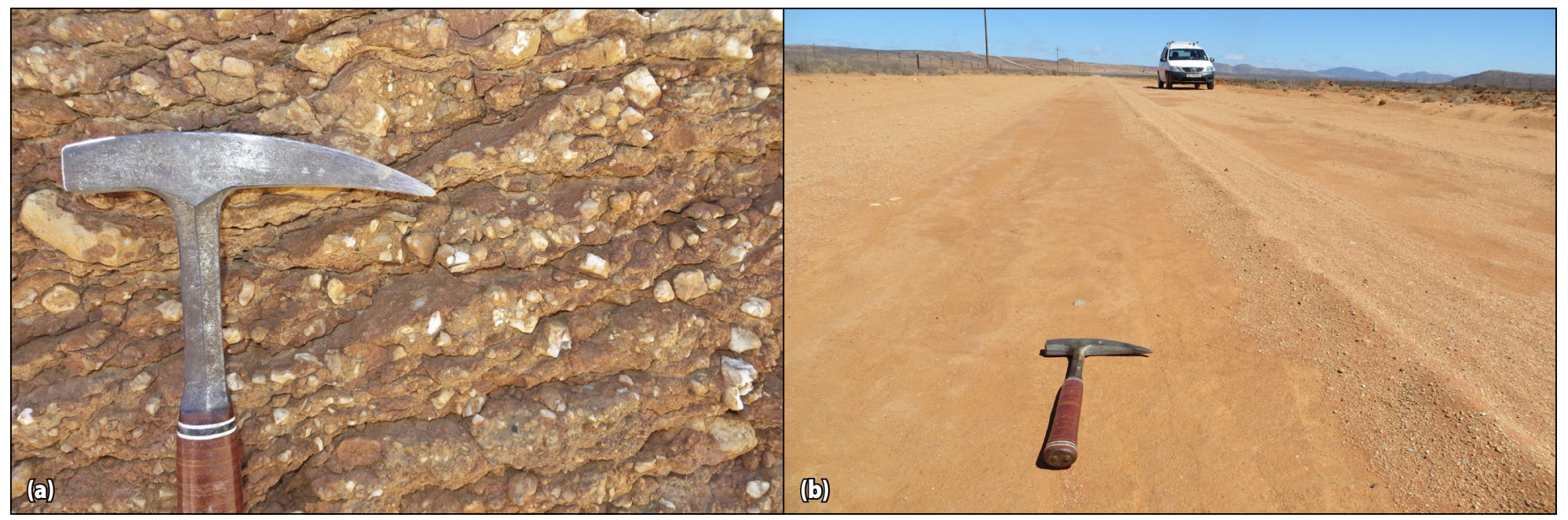

Figure 2 (a) Platy dorbank in an old gypsum quarry near Vanrhynsdorp, (b) Polished surface of in-situ dorbank on the R358 between Bitterfontein and Kliprand, Northern Cape

material. Poor maintenance of some of the Northern Cape roads resulted in stretches where the road has been worn down to the underlying in-situ dorbank, exposing it to direct abrasion by traffic and repeated scraping by road graders (Figure 2(b)).

Another key difference between pedocretes and traditional materials is attributed to their variation in strength with depth.

The engineering quality of rocks tends to increase with depth, but pedocretes, especially those found in arid and temperate regions, show a reversal of this rule. The strength of aggregates also tends to increase with aggregate size (Netterberg 1971) and with the amount of cementing agent present (De Graft-Johnson 1975). Also, lateral and vertical heterogeneity of pedocretes are common, and the porous nature of particles makes them unsound to a certain extent (McNally 1995). However, Netterberg (1971) found a good correlation between aggregate strength values from the $10 \%$ FACT test and the Mohs hardness of the cement of calcrete.

There is a wealth of examples of how naturally occurring minerals impose deleterious characteristics on unbound gravels and aggregates (Zivica \& Bajza 2001; PaigeGreen 2003; Ekblad 2007; Mshali \& Visser 2012). In the case of dorbank, soluble salts, reactive silica and in some cases clay minerals, may be present in quantities that could affect road building according to pedological research (Ellis \& Schloms 1981; Francis et al 2007). In unpaved roads the effects of soluble salts are less pronounced and, in particular cases, even lower the dust content where enough atmospheric moisture is available (Netterberg \& PaigeGreen 1998). Amorphous silica and cryptocrystalline quartz have strong pozzolanic (cementing) reactions with alkaline pore solutions, sometimes an unwelcome feature in cement-stabilised materials (McNally 1995; Paige-Green 2003). Where road materials containing amorphous silica are treated with lime they form expansive alkali (tobermorite) gels, as found by Netterberg (1971) in calcrete gravels, but where modification with lime is not required it may have welcome stiffening properties by natural self-cementation in soil moisture (McNally 1995). Active clay minerals have been found in pedocretes (Netterberg 1971; Watts 1980), but clay minerals may be clustered and coated with cementing agents, behaving rather like detrital particles. For example, Netterberg (1982) also often found their plastic limits to be lower than the shrinkage limits, resulting in negative shrinkage indices. The tendency of fines to absorb water, produces exaggerated liquid limits and plasticity, which are not really representative of the amount of clay or activity of clays present. In the case of calcretes, this has been accommodated for in the COLTO green book, where the specific plasticity index and linear shrinkage were amended for calcrete G4 and G5 materials (COLTO 1998).

Mechanical deformation of an unbound layer in a pavement depends on the layer material's stiffness and stability, and is best reflected in the measure of bearing capacity. The overall particle shape influences both the shear strength and the compactability of a granular material (Nouguier-Lehon et al 2003; Fannin et al 2005; Tutumluer et al 2006; Mishra et al 2010).

Grain-size distribution influences packing efficiency. Grain-size distributions of crushed pedocretes may differ vastly from those achieved by standard laboratory crushing and compaction methods (McNally 1995) and, as a result, the TRH 14 manual suggests selection on slightly higher crushing strengths (CSRA 1990). Jaw crushers, relevant to this study, are normally applied in the initial stage of crushing rock and tend to produce more elongated fragments than products of cone and impact crushers (Räisänen \& Mertamo 2004; SANRAL 2014). It is also suggested that, due to the porous nature of grains and the resulting high absorbance of water, samples should be cured in water overnight to allow water moisture equilibration before compaction (Brink 1985).

\section{MATERIALS AND METHODS}

\section{Material sourcing}

The sampling procedure was developed around the aim to investigate dorbank representing different regions and morphological types. In total, eight samples of between 15 and $20 \mathrm{~kg}$ each were taken in three general areas - an old gypsum mine at Vanrhynsdorp, the Vaalputs nuclear disposal site and around the mining town of Aggeneys, most of which were sampled along the access road to the Gamsberg zinc mine. After proper procedural descriptions of the soil profiles, according to the methods outlined by Brink and Bruin (2002), samples were taken from the walls of old borrow pits and nuclear disposal pits, taking care not to include material from presumably long-exposed dorbank. The dorbank layers were classified according to the schematic presentation in Figure 1. The only amendment made to this system was the use of the term "dorbank" instead of hardpan, since dorbank is per definition a hardpan soil horizon (Soil Classification Working Group 1991). 


\section{Testing procedure}

The study constituted two phases of investigation. Firstly, the petrographic study of dorbank, aimed at describing the texture of the host material, the mineralogical and chemical characteristics of cementing agents, and the macroscopic fabric and morphological characteristics of the samples. The second phase of the testing regime involved the determination of the engineering properties of crushed dorbank.

During the first stage, fist-size subsamples were split and cut into small tiles, polished and mounted in an epoxy resin and coated with gold. This was done in preparation for use in a Zeiss Merlin scanning electron microscope (SEM) equipped with a backscatter electron (BSE) detector and energy dispersive x-ray (EDX) analyser. A novel method, based on the procedure experimented by Singh and Gilkes (1993), was used to determine the enrichment by silica of areas in specimen matrices containing largely clay minerals, as a measure of the level of induration reached by cementation.

As part of the first stage of the study, the nature of cementing agents was qualitatively analysed based on the knowledge that hydrochloric acid reacts with carbonates, and amorphous iron oxides and sodium hydroxide react with amorphous silica. Grains of between 13-16 mm, and passing the aggregate pliers test (see Table 1), were analysed according to the IUSS definition of a petroduric horizon (IUSS 2016). After two days of soaking in distilled water, four grains from each sample were air-dried and submerged first in $1 \mathrm{M} \mathrm{HCl}$ and heated over a steam-bath, until equilibration was reached, and then in $6 \mathrm{M} \mathrm{NaOH}$. The resultant disintegration of grains was noted by comparison of photographs captured every 12 hours. In a parallel test, grains were submerged in gently heated $2 \mathrm{M} \mathrm{HCl}$ and $2 \mathrm{M} \mathrm{NaOH}$ respectively, according to the methods suggested by the Non-Affiliated Soil Analyses Work Committee (SSSSA 1990), whilst assessing the supposed loss in strength by gently tapping grains with a pestle every 24 hours and noting the changes.

In the second phase of the testing regime, the tests listed in Table 1 were performed.

The dorbank samples were crushed by a standard jaw crusher to a maximum size of $37.5 \mathrm{~mm}$. The maximum dry density, optimum moisture content and California Bearing Ratio were determined for material

Table 1 Summary of the parameters tested and standard procedures followed (CSRA 1986; ASTM 2011; Netterberg 1967)

Unbound Property

Particle Size Distribution (PSD) and Hydrometer Analysis

Maximum Dry Density (MDD) and Optimum Moisture Content

California Bearing Ratio (CBR) and Swell

Atterberg Limits (PL, LL \& PI) and Linear Shrinkage (LS)

Treton Impact Test

Aggregate Plier Test (APT)

Flakiness Index (FI)

Accelerated Weathering Test (AWT)

$\mathrm{pH}$ and Electrical Conductivity

Direct Shear Strength

Table 2 Sample names, regions and the mixtures made for tests requiring greater quantities of material

\begin{tabular}{|c|c|c|c|}
\hline Area & Sample ID & Coordinates & Mixture ID \\
\hline \multirow{3}{*}{ Vanrhynsdorp } & WN & $31^{\circ} 24^{\prime} 18.87^{\prime \prime} S, 18^{\circ} 35^{\prime} 28.83^{\prime \prime} \mathrm{E}$ & \multirow{3}{*}{ Vanrhynsdorp } \\
\hline & $\mathrm{RB}$ & $31^{\circ} 24^{\prime} 17.91^{\prime \prime} S, 18^{\circ} 38^{\prime} 0.56^{\prime \prime} \mathrm{E}$ & \\
\hline & N7 & $31^{\circ} 14^{\prime} 53.65^{\prime \prime} \mathrm{S}, 18^{\circ} 32^{\prime} 27.09^{\prime \prime} \mathrm{E}$ & \\
\hline \multirow{3}{*}{ Vaalputs } & VP1 & $30^{\circ} 8^{\prime} 22.50^{\prime \prime} \mathrm{S}, 18^{\circ} 34^{\prime} 24.74^{\prime \prime} \mathrm{E}$ & \multirow{3}{*}{ Vaalputs } \\
\hline & VP2a & $30^{\circ} 8^{\prime} 22.50^{\prime \prime} \mathrm{S}, 18^{\circ} 34^{\prime} 24.74^{\prime \prime} \mathrm{E}$ & \\
\hline & VP2b & $30^{\circ} 8^{\prime} 22.50^{\prime \prime} \mathrm{S}, 18^{\circ} 34^{\prime} 24.74^{\prime \prime} \mathrm{E}$ & \\
\hline \multirow{4}{*}{ Aggeneys } & AG2 & $29^{\circ} 24^{\prime} 1.60^{\prime \prime} \mathrm{S}, 19^{\circ} 8^{\prime} 49.44^{\prime \prime} \mathrm{E}$ & \multirow{4}{*}{ Aggeneys } \\
\hline & AG3 & $29^{\circ} 20^{\prime} 15.70^{\prime \prime} \mathrm{S}, 19^{\circ} 3^{\prime} 7.86^{\prime \prime} \mathrm{E}$ & \\
\hline & AG4 & $29^{\circ} 18^{\prime} 34.42^{\prime \prime} \mathrm{S}, 19^{\circ} 0^{\prime} 27.82^{\prime \prime} \mathrm{E}$ & \\
\hline & AG5 & $29^{\circ} 17^{\prime} 5.96^{\prime \prime} \mathrm{S}, 18^{\circ} 58^{\prime} 3.12^{\prime \prime} \mathrm{E}$ & \\
\hline
\end{tabular}

passing the $19.0 \mathrm{~mm}$ sieve from the regional mixtures shown in Table 2.

The aggregate strength of dorbank was evaluated using two testing procedures requiring less material than the conventional ACV or 10\% FACT tests. Results from both the aggregate pliers test (APT) (collective name for the Aggregate Pliers and Aggregate Fingers procedure) and the Treton impact test used in this study, have been shown to present a positive relationship with the results of aggregate crushing value $(\mathrm{ACV})$ and the $10 \%$ fines aggregate crushing value (10\% FACT) tests (Brink 1985). The APT is a two-stage procedure developed by Netterberg (1967) as a rapid strength indicator which involves the testing of more than 100 pieces of the 13.2-9.0 $\mathrm{mm}$ size range for failure inbetween the thumb and forefinger of two hands, and subsequently in the serrated jaw of a $180 \mathrm{~mm}$ standard plier, and recording the nominal percentage unbroken pieces from the total.
The Treton impact test, which is based on the same principles as the British aggregate impact test (AIT) and outlined in TMH1 method B7, involves dropping a hammer in a cylinder on the $16-19 \mathrm{~mm}$ grains, recording the material retained on a $2.00 \mathrm{~mm}$ sieve after ten blows and then expressing the weight loss as a percentage of the original sample (Treton Value).

This study made use of a comparative accelerated weathering test (AWT) to assess the weather ability of dorbank. The test apparatus was a rotating drum mechanism (constructed at Stellenbosch University) that complies with the American Society for Testing and Materials test designation D4644 for testing the slake durability of rocks. The mechanism comprises a single rotating axle with four $100 \mathrm{~mm}$ wide, $250 \mathrm{~mm}$ diameter polyvinyl chloride (PVC) bins, each fitted with $13 \mathrm{~mm}$ wire mesh on either side, and $20 \mathrm{~mm}$ holes through the PVC casing. Seven particles, of between 36.5 and 
$26.5 \mathrm{~mm}$ in diameter and passing the AFT test, from each sample were placed in the bins and the axle set to rotate at five rotations per minute. The assembly was rotated for five days with 12-hour wet and dry cycles, administrated through submergence of the lower half of the bins in distilled water during wet cycles and removal of the water during air-drying cycles whilst monitoring temperature changes. After the five days of rotation, samples were ovendried and the retained mass expressed as a percentage of the original dry mass.

The shear strength of material passing the $19.0 \mathrm{~mm}$ sieve was determined in a square $(60 \times 60 \mathrm{~mm})$ direct shear apparatus for material remoulded by the Proctor compaction effort and the MOD compaction effort. Shear speed was set to $0.001 \mathrm{~mm} / \mathrm{min}$ and normal stresses of $50 \mathrm{kPa}, 100 \mathrm{kPa}$ and $200 \mathrm{kPa}$ were applied respectively. Finally, comparisons could be drawn between inherent features of dorbank and its qualities as an unbound material.

\section{RESULTS AND DISCUSSION}

\section{Natural characteristics}

It is clear that the soil profiles containing dorbank are very different, and there is little consistency between dorbank from different sites. For example, thicknesses vary from as thin as $0.2 \mathrm{~m}$ to $1.5 \mathrm{~m}$, and hues of yellow, brown and red. However, a number of easily observable parallels were found:

- Dorbank exists just beneath the topsoil and above the permanent water table.

- Occurrences are restricted to transported soils, i.e. aeolian sands, hillwash and alluvium.

- Host soil textures are always between sandy and clayey-sands.

- Boundaries of platy dorbank layers are well defined.

From scanning electron microscope analysis, specimens from the Aggeneys area are porous in nature and consist of medium to coarse-grained particles with bridges of kaolinite and silica-rich cement, whilst specimens from Vanrhynsdorp and Vaalputs are fine to medium-grained and less porous. Most of the pore spaces are filled with illite and smectite clay, mixed with either siliceous or calcerous cement or a combination of both. Assuming all aluminium is accounted for by the presence of clay minerals in cemented areas of between $100-900 \mu \mathrm{m}^{2}$, the relative enrichment of

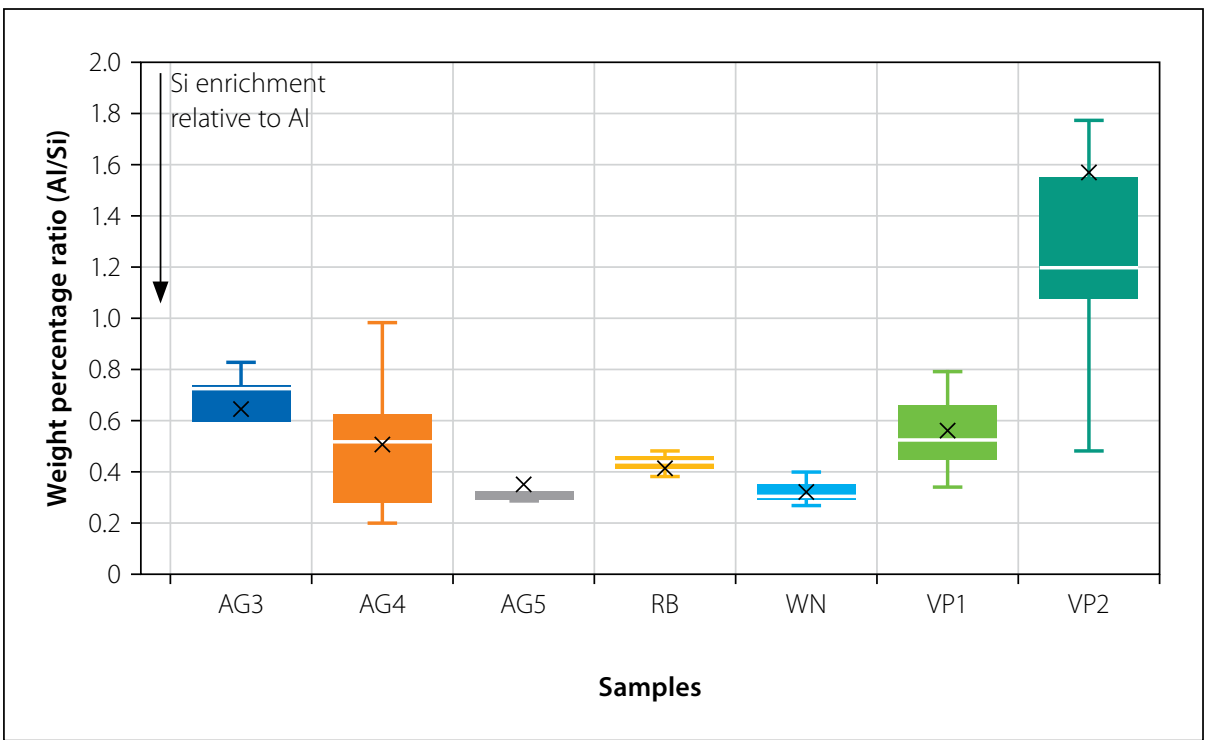

Figure 3 Aluminium / silica ratios by weight percent of dorbank samples, after accounting for silica from clay minerals; boxes provide the median, 1st and 3rd quartiles, the "whiskers" the uppermost and lowermost values, and the crosses the mean values

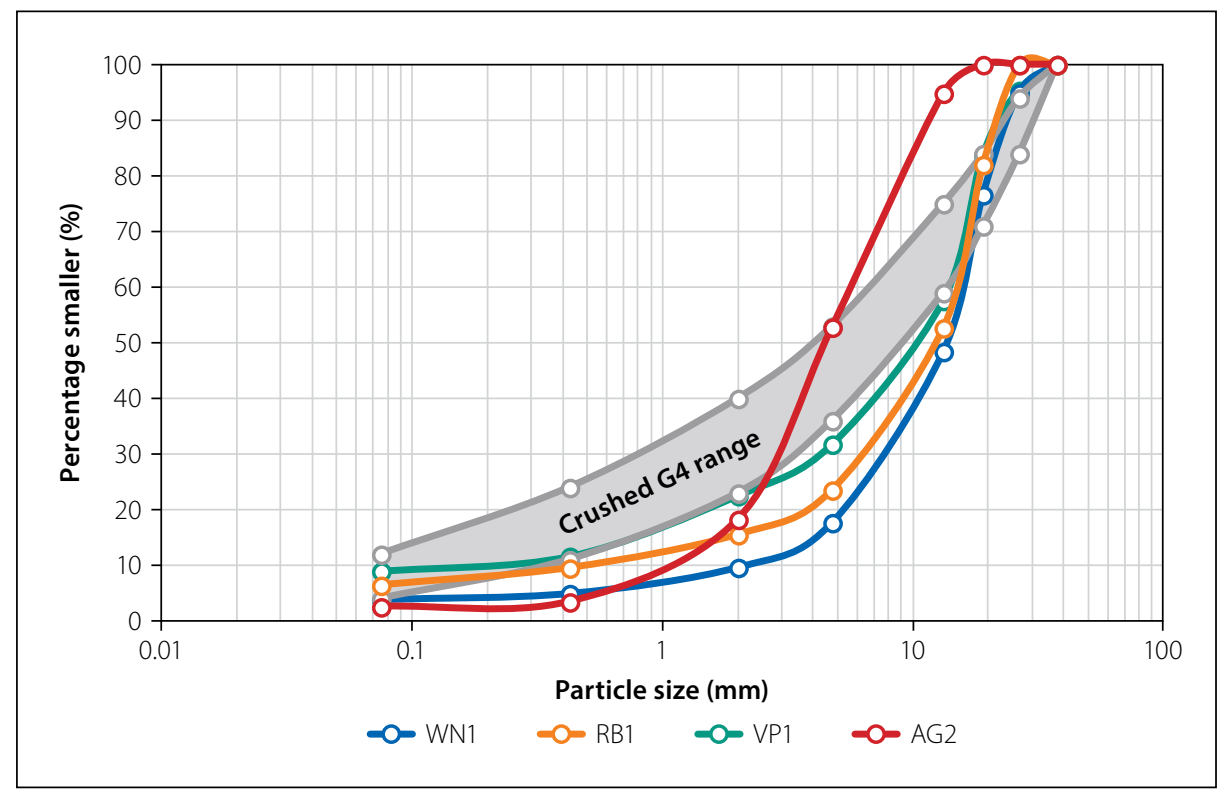

Figure 4 Particle size distribution after crushing with the jaw crusher to a nominal maximum size of $37.5 \mathrm{~mm}$

silica can be calculated in its condensed form in a statistical plot, as shown in Figure 3.

\section{Shape and size distribution}

Apart from sample AG2 from Aggeneys, dorbank samples are coarser-grained than the required envelope for G4 materials (Figure 4). The grading moduli of samples are high, between 2.57 and 2.82. This is an indication of coarse grading and a shortage of clay to provide plasticity, and would need modification if crushed by a small jaw crusher to comply with requirements.

A generally finer grain size distribution in AG2 can be attributed to the poor strength of its larger aggregates, as revealed by the results in the aggregate strength tests.

\section{Deleterious minerals}

Whilst the material passing the $0.425 \mathrm{~mm}$ sieve behaved non-plastically in the indicator tests, and experienced no significant swell from soaking for a period of four days after being remoulded, the SEM-EDX spectra and backscatter images revealed the presence of active clays such as vermiculite. These were all found in association with amorphous silica (see Figure 5). It is conceivable that, after crushing dorbank, the silt and clay fractions are made up mainly of aggregated clusters of cemented clay minerals that remain fairly inert and behave like detrital grains. More rigorous 


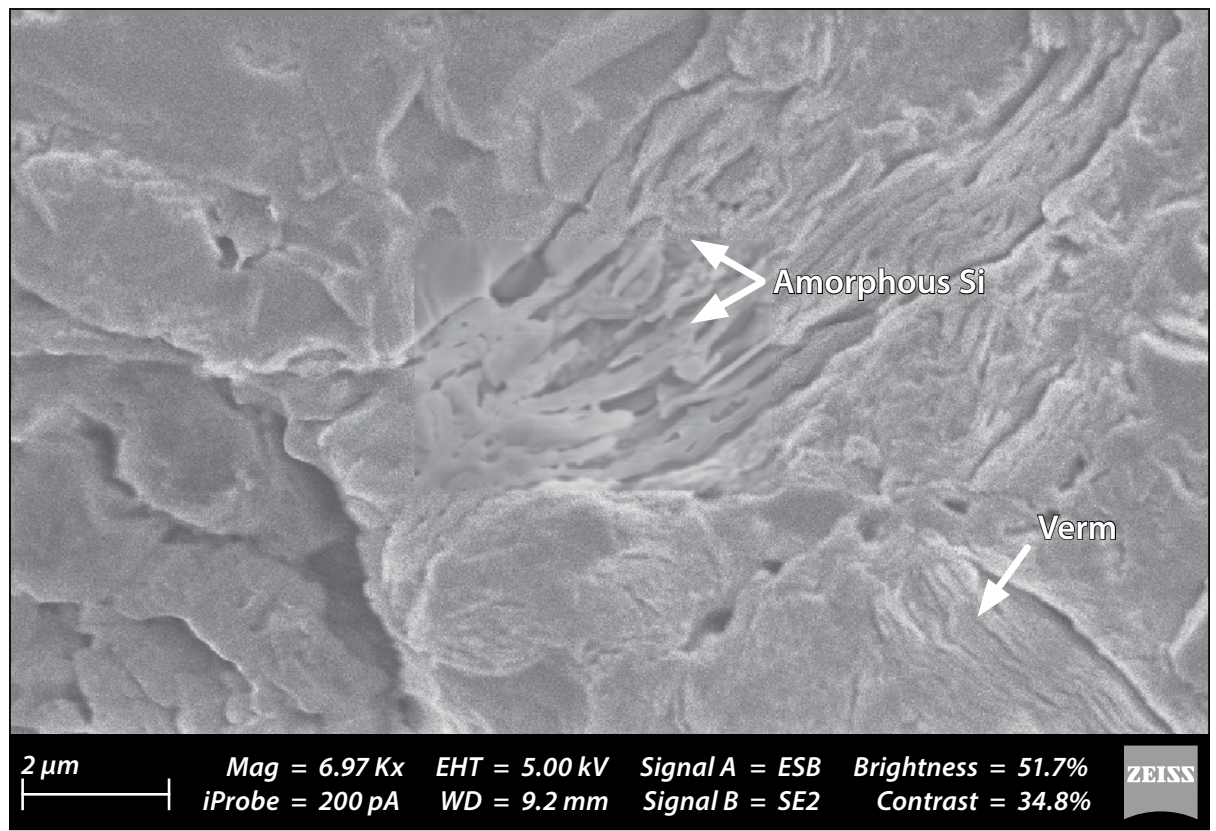

Figure 5 Micrograph produced by energy selective backscatter (ESB) detector showing vermiculite in specimen $\mathrm{RB}$; where $\mathrm{KI}=$ kaolinite, $\mathrm{Si}$ = silica
The electrical conductivity (EC) of sample RB from Vanrhynsdorp is particularly high $(3.24 \mathrm{mS} / \mathrm{cm}$ ) (see Figure 7$)$, and exceeds the specified maximum (COLTO 1998). Upon closer inspection with SEMEDX analysis, the sample was found to be rich in calcium phosphates in the soil matrix (see Figure 8).

Calcium phosphates exist as a range of mineral salts, such as apatite $\left(\mathrm{Ca}_{5}\left(\mathrm{PO}_{3}\right)_{4}(\mathrm{~F}, \mathrm{Cl}, \mathrm{OH})\right)$, and are prone to dissolution at room temperatures and low $\mathrm{pH}(<6)$. The problem is confined only to sample RB from Vanrhynsdorp, which overlies a calcareous shale bed containing phosphates.

\section{Aggregate strength and durability}

The morphology of particles influences the strength of dorbank particles. The standard method used to determine the APV in this

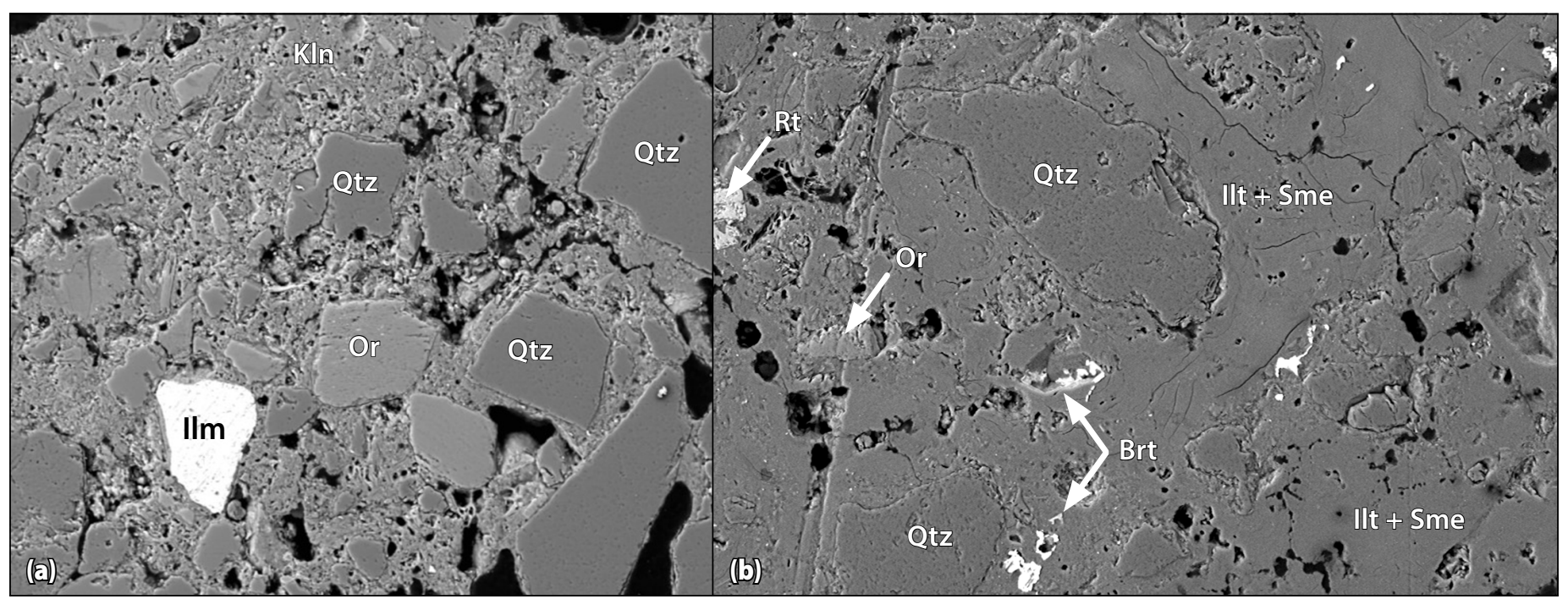

Figure 6 Electron backscatter (BSE) micrographs of polished sections of specimens AG4 (a) and WN (b) at scale $100 \mu \mathrm{m}(\mathrm{Brt}=\mathrm{barite}, \mathrm{llm}=\mathrm{ilmenite}$, Ilt $=$ illite, Or = orthoclase feldspar, $\mathrm{Qtz}=$ quartz, Rt = rutile, Sme = smectite)

techniques of crushing and separation of fines could promote the plastic behaviour of some dorbanks.

By the natural process that forms dorbank, clay and cementing agents are eluviated from hosting soils and concentrated in the dorbank layer. The plasticity of the soil hosting dorbank can also be tested if there are concerns that dorbank may develop more plastic behaviour in its design life, although the soil profiles hosting dorbank in this study are mostly well drained, with little clay and silt. In general, the primary minerals found in dorbank are not harmful to engineering works, but depend on the host material (Figure 6).

From the samples tested there is no evidence of salt content, purely as a result of the typical mechanism of dorbank formation.

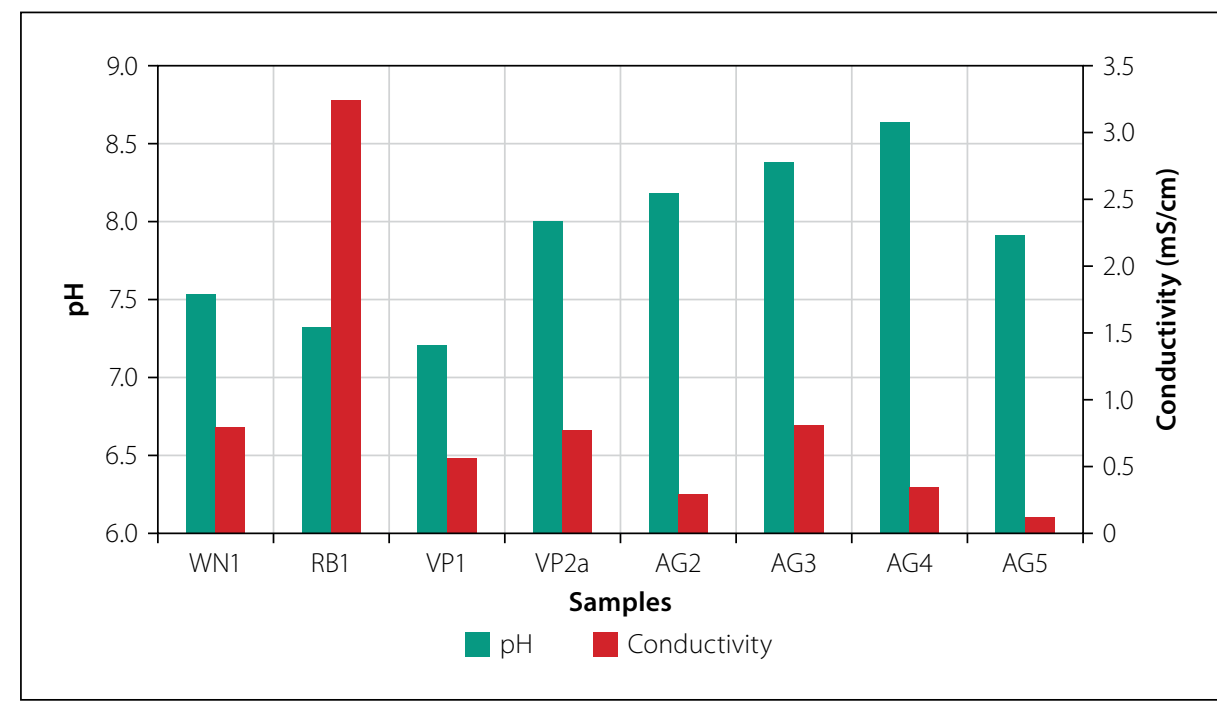

Figure $7 \mathrm{pH}$ and conductivity of saturated pastes; the conductivity of all samples apart from sample RB falls within the specifications of COLTO for crushed natural samples before lime-stabilisation, but all pH measurements were within bounds 


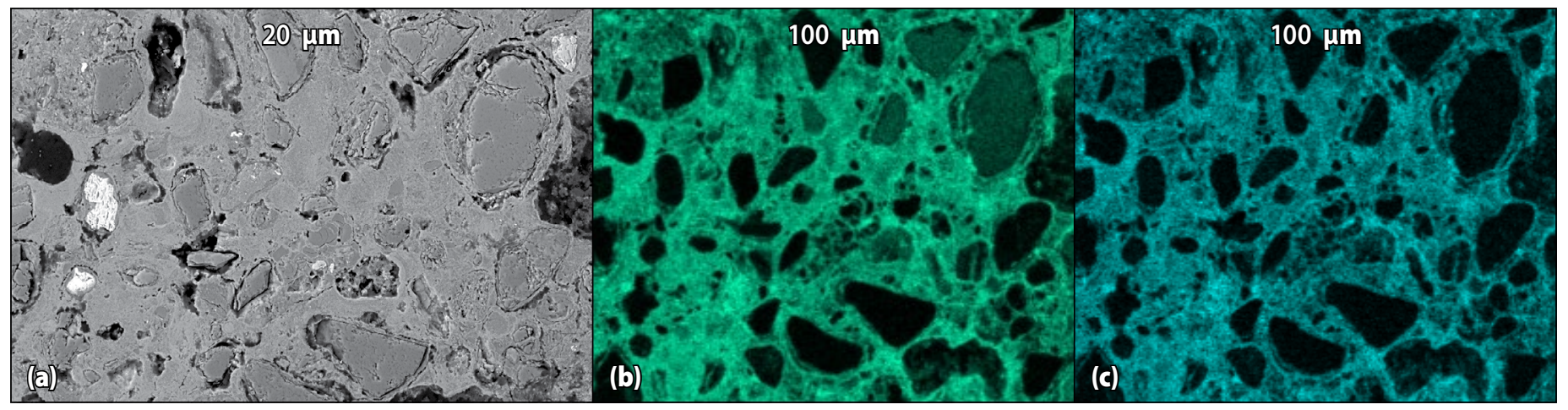

Figure 8 (a) Backscatter electron image and distribution maps of the concentration of (b) calcium (green) and (c) phosphorous (blue) of a polished specimen from sample RB

study required that grains were placed with their longest dimension on the plier's jaws (i.e. not on the edges) resulting in an applied force perpendicular to the natural fabric of flaky particles. In the Treton cylinder, gravitational settling may cause the same effect. Conceivably, the correlation between APV and the Treton values are better than in the case of AFV and Treton values.

By a linear regression analysis, the relationship between the Treton test and the APT can be written as

$\mathrm{TIV}=0.83-1.39 \mathrm{APV}, r^{2}=0.86$

Where:

TIV = Treton impact value (weight $\%$ not retained)

APV = Aggregate pliers value (\% particles withstanding test)

The correlations of dorbank from the same regions with strength performance appear to be more prominent, suggesting the significance of intrinsic factors of different areas influencing strength.

The APV recommended in TRH 14, as a quality evaluation for calcrete wearing courses of gravel roads, is between $20 \%$ and $75 \%$. In a suggested improvement of specifications for gravel wearing courses by PaigeGreen (2007), upper and lower limits for Treton impact values are given as between $20 \%$ and $65 \%$. Materials with Treton values greater than $65 \%$, such as the samples from Aggeneys, tend to break down under compaction by a roller and traffic. It is uncertain if these recommendations can be applied to dorbank, but if so, dorbank performs poorly. Dorbank samples from the Vanrhynsdorp area comfortably satisfy these requirements and those from Vaalputs are borderline-soft material, whilst Aggeneys dorbank is far too frail (see Figure 9). Therefore, it seems that inherent differences across different regions

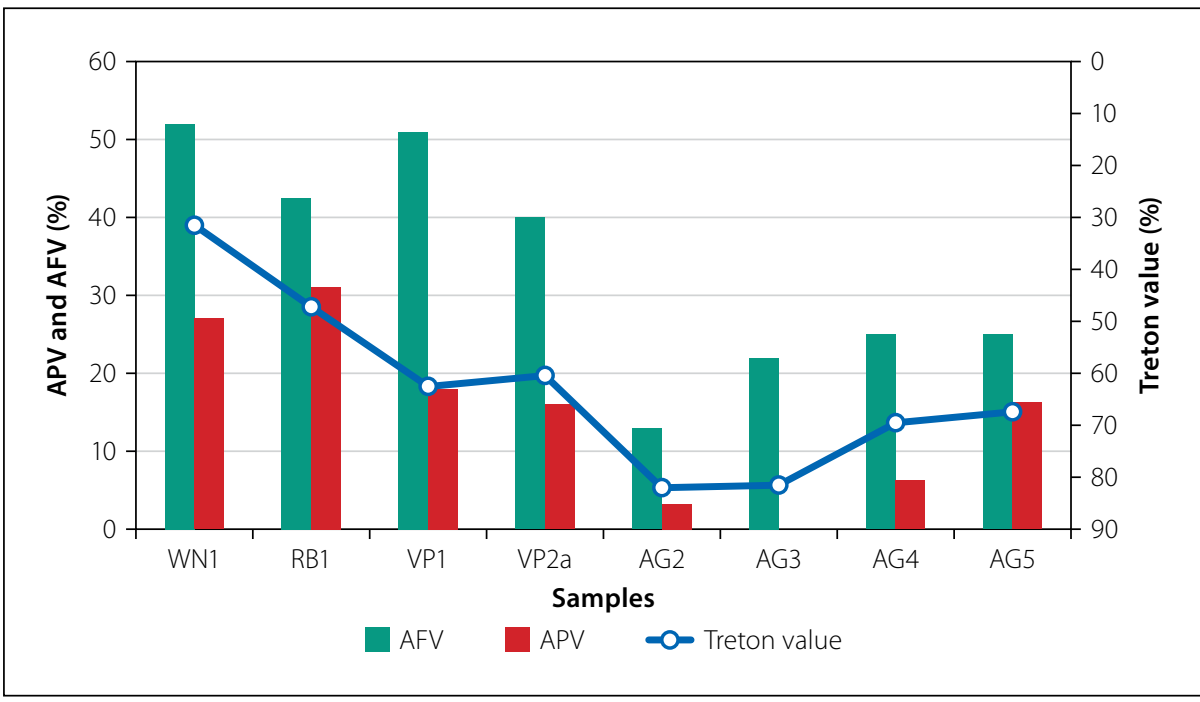

Figure 9 Results from dry aggregate plier tests and Treton impact tests; note that the Treton values are plotted on an inverse scale to show the relationship with the APT more visually

significantly impact the strength performance of aggregate grains.

From the results of the accelerated weathering test (AWT), dorbank is less durable than the conventional material from the Matjiesfontein area tested by Van Wyk (2013) with the same apparatus. The reproducibility of such a test is questionable, and many replications should be done to obtain results representative of the whole. Nonetheless, the nature of individual grains that withstood the tumbling action and wetting and drying cycles, was somewhat revealing. Particles that withstood the tumbling and rolling action the best were more equidimensional to start with, and had no intrinsic layering (i.e. massive). From the perspective of regional grouping, the massive dorbank from Vaalputs faired the best in this test, as apposed to the platy dorbank samples from Vanrhynsdorp.

The twelve-hour submergence in water before the selective dissolution test caused no dispersion or weakening of particles, indicating inactivity of clay minerals in the dorbank structure. Carbonates and iron oxides are not a source of the primary strength of dorbank, which is attributed to amorphous silica from strength failure during dissolution tests. Where failure of particles occurred in the $\mathrm{HCl}$ solution, it occurred as large fractures along calcrete or calcerous soluans.

The nature of soil types hosting dorbank certainly influences the morphology of dorbank, and therefore also its strength and durability:

- Dorbank aggregates from soil hosts with a greater amount of silt and clay were more durable in the APV, APT and Treton tests.

- There is a positive association between dorbanks in finer-grained soil hosts and a platy morphology, which in turn influences the performance in strength tests (see previous bullet).

- The presence of calcerous soluans influences the consistency of dorbank beds, creating planes along which failure can occur.

\section{Mechanical behaviour}

The compaction abilities of dorbank are relatively poor, the highest modified 


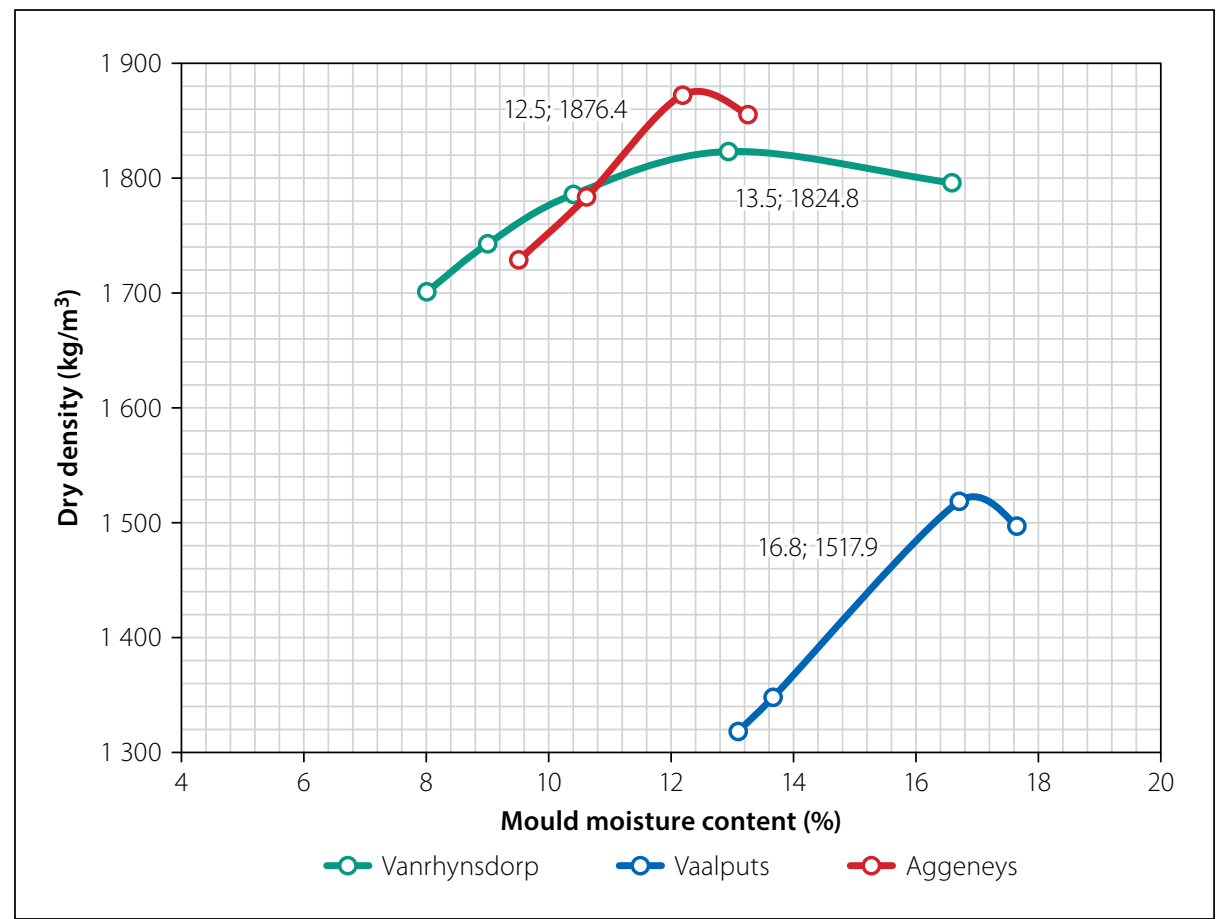

Figure 10 Results of compaction by modified AASHTO effort at different mould moisture contents

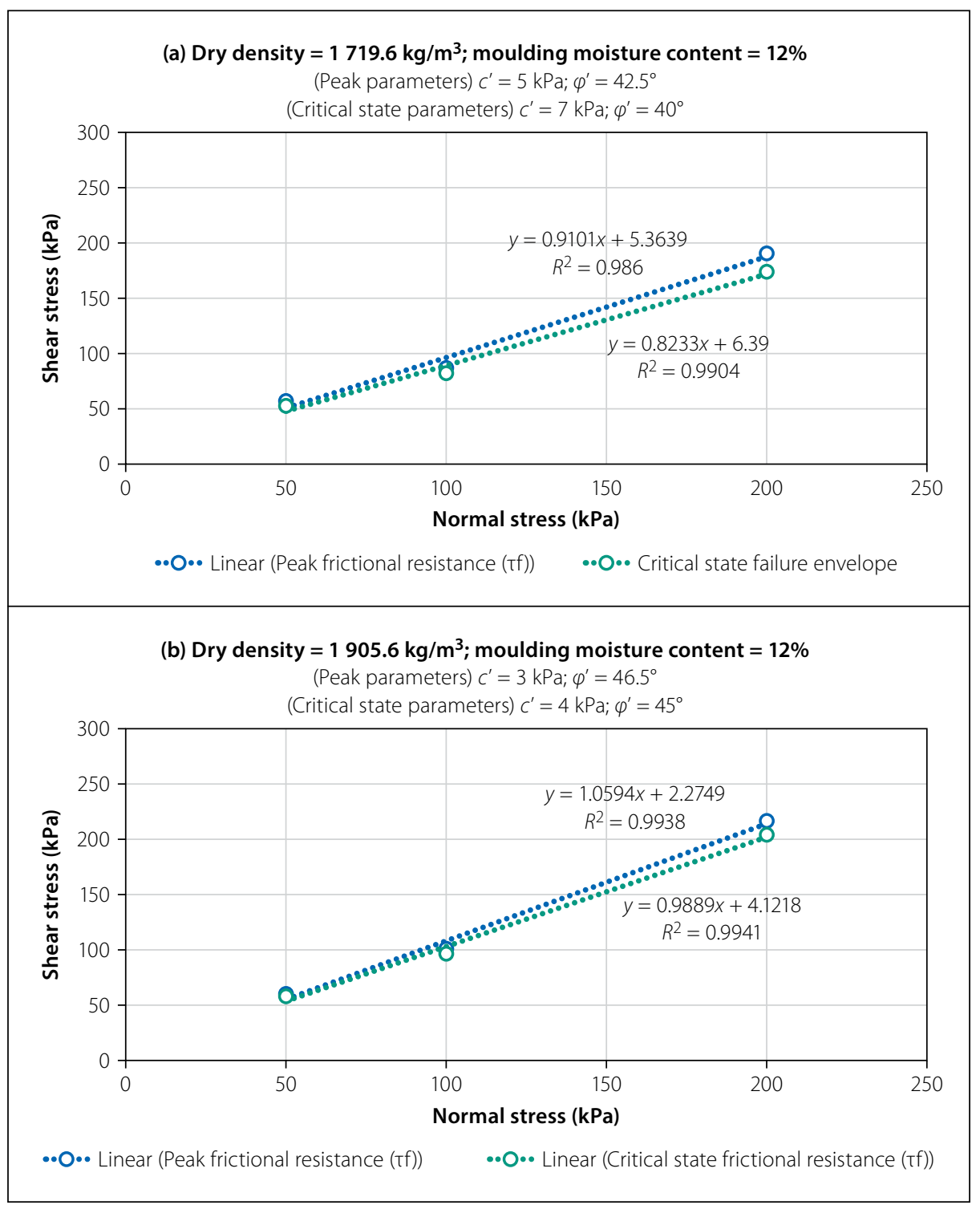

Figure 11 The relationship between shear stress and normal stress for the peak and critical states of the two sets of sub-samples
AASHTO dry density being $1876.4 \mathrm{~kg} / \mathrm{m}^{3}$ (Aggeneys mixture). This can be attributed to the coarse sand grading of crushed dorbank. In the case of the Vanrhynsdorp mixture, a relatively flat compaction curve (refer to Figure 10) is indicative of a low sensitivity towards change in moisture content.

The bearing strength of dorbank is very low, according to the soaked CBR results. Generally, standard deviations of CBR results are high, and engineers often struggle to produce consistent outcomes (Gregory \& Cross 2007). Even bearing this in mind, the CBR values are still very low. The cohesionless properties were further highlighted by the direct shear test (DST) results (Figure 11). The apparent cohesion values at densities $1906 \mathrm{~kg} / \mathrm{m}^{3}$ and $1720 \mathrm{~kg} / \mathrm{m}^{3}$ are close to zero, confirmed by the Atterberg limit results, but also expected from the coarse grain-size distribution.

Evidently, the grain size distributions of dorbank will need improvement by the addition of fines to increase packing efficiency and remoulding abilities, supporting the particle size distribution results not conforming to the suggested envelopes.

A good relationship between the tested California Bearing Ratio of materials and the ultimate bearing capacity $\left(R^{2}=0.9788\right)$ was found by Gregory and Cross (2007), based on the bearing capacity equation for vertical loading by Meyerhof (1963). The relationship at $2.54 \mathrm{~mm}$ penetration depth of a standard CBR apparatus with a piston-base area of $1620 \mathrm{~mm}^{2}$ and $54.4 \mathrm{~N}$ surcharge weight can be written as:

$\mathrm{CBR}=\frac{q_{\text {ult }} \times 100}{6895}$

The predicted bearing ratios $(29.9 \%$ and $19.9 \%)$ are much higher than the tested CBR at $2.54 \mathrm{~mm}$ penetration depth $(18.9 \%$ and $14.7 \%$ ). In a study on this standard procedure of crushing oversized material and its effects on variation in CBR results, Savage (2014) found a significant increase in the variability of results in relation to the amount of oversized material that required crushing. For samples containing $30 \%$ and $40 \%$ oversized material the variations from mean CBR results are between $20 \%$ and $43 \%$, and between $30 \%$ and $75 \%$ respectively (Savage 2014). The CBR values obtained in this study may well be indicative of the same kind of variation (oversized material was greater than 30\%). CBR as a design standard received negative 
critique, because it is not based on a testing program, but rather on the notion that density has a positive linear relationship with strength (Sanchez-Leal 2002).

A further possible explanation is the influence that the soaking period has on pedogenic materials. Strength loss due to soaking is apparent in both lateritic and gypsiferous soils (Ampadu 2007; Razouki \& Bushra 2016).

\section{Gravel wearing course considerations}

The recommendations made in TRH 20 have been compiled to compensate a lack of experience and included in the Standard Specifications for Road and Bridge Works for State Road Authorities (COLTO 1998). The grading coefficient (GC) should be between 16 and 34 for unpaved rural roads (COLTO 1998). Apart from AG2, the samples' grading coefficients fall close to the lower end of the recommended coefficients, emphasising the low proportion of finergrained fractions. This is also highlighted when grain size distributions are compared with the grading envelope recommended in TRH 14 (see Figure 4), where material passing the $13.2 \mathrm{~mm}$ sieve is proportionally lower than recommended. Material passing the $0.425 \mathrm{~mm}$ sieve behaves nonplastically, and the authors were unable to obtain Atterberg limits and bar linear shrinkage limits by the methods in TMH 1 (CSRA 1986).

Extensive research of unpaved roads in South Africa has led to performance predictions based on the relationship between the grading coefficient (GC) and the shrinkage product $(\mathrm{SP}=$ linear shrinkage $\times$ percentage passing the $0.425 \mathrm{~mm}$ sieve) (CSRA 1990). The cohesionless nature of dorbank will be susceptible to form corrugations and cause ravelling (formation of loose material). Cohesionless gravel courses require regular material replenishment and scraping with a grader blade, and, should dorbank gravel not be modified to increase the cohesion, this will be a problem. Whilst road dust is predominantly silt-sized particles (0.002-0.075 mm), most roads materials will produce dust regardless of the amount of silt they contain. The best probability of acceptable dust levels in South Africa were found for materials with SP values of between 100 and 240, a requirement that dorbank does not satisfy.

A well-graded gravel course is also necessary to combat gravel loss. The
TRH20 manual proposes the use of a gravel prediction model accurate to within $11 \mathrm{~mm}$ per annum, based on the findings of PaigeGreen (1989):

$$
\begin{aligned}
\mathrm{AGL}= & 3.65[\mathrm{ADT}(0.059+0.0027 \mathrm{~N}- \\
& 0.0006 \mathrm{p} 26)-0.367 \mathrm{~N}-0.0014 \mathrm{PF}+ \\
& 0.0474 \mathrm{p} 26]
\end{aligned}
$$

(5.5 in Paige-Green 1989)

Where:

$$
\begin{aligned}
\mathrm{AGL}= & \text { annual gravel loss }(\mathrm{mm}) \\
\mathrm{ADT}= & \text { average daily traffic } \\
\mathrm{N}= & \text { Weinert N-value (see Section 2.3.2: } \\
& \text { Durability in Paige-Green } 1989) \\
\mathrm{p} 26= & \text { mass percentage passing the } \\
& 0.26 \mathrm{~mm} \text { sieve } \\
\mathrm{PF}= & \text { product of plastic limit and mass } \\
& \text { percentage passing } 0.075 \mathrm{~mm} \text { sieve }
\end{aligned}
$$

According to the aggregate hardness recommendations by Paige-Green (2007), based on Paige-Green and Bam (1995), dorbank from the Aggeneys area (AG2-AG5) is too "soft" for usage, whereas dorbank aggregates from the Vanrhynsdorp and Vaalputs areas are well within the requirements. This was echoed by the APV and APT results, where Aggeneys samples do not meet the lowest hardness requirements for calcrete wearing courses. The breakdown of large aggregates causes excessive loose material and increases the susceptibility to ravelling, all the while increasing the maintenance needed.

\section{Considerations for flexible pavement structures}

According to the recommendations (CSRA 1990; COLTO 1998), dorbank can be classified as G6 or G5 quality gravel at best, the biggest drawback being the low CBR strength. As for the recommended flakiness index, Atterberg limits, electrical conductivity and percentage swell, most dorbank samples meet the requirements of a G4 material. On the other hand, their particle size distributions would need modification to become a G4 or even a G5 material (Figure 4). Only sample VP1 from Vaalputs satisfies the G5 grading requirement. All samples are coarse-grained, and are particularly void in material passing the $2 \mathrm{~mm}$ sieve.

\section{CONCLUSIONS AND \\ RECOMMENDATIONS}

There are intricate relationships between the nature of dorbank and its host soil, and between dorbank and calcrete, where they are found in association, with implications on how they respond to engineering tests. For example:

- Morphology has an influence on aggregate impact and strength tests - platy dorbank resists disintegration in the Treton test, and produces higher AFV and APV.

- The activity and cohesion of clay minerals are not well expressed in conventional Atterberg limit tests and direct shear tests, probably because of suppression by cementing silica.

- The strength of aggregate particles influences the grain-size distribution of material greater than $2 \mathrm{~mm}$ in size, i.e. dorbank with a low aggregate strength contained less material between $2 \mathrm{~mm}$ and $37.5 \mathrm{~mm}$.

- Internal weaknesses, such as calcerous soluans and dorbank laminae, reduce the durability of dorbank.

- A fair correlation exists between the Treton value and the aggregate pliers value of dorbank.

As a crushed granular material, dorbank revealed three undesirable traits - a low soaked strength, deficiency in material passing the $2.00 \mathrm{~mm}$ sieve (GM between 2.57 and 2.82), and a seemingly high affinity towards weathering. Dorbank also weathers much quicker than other natural material from the Karoo, such as tillite, shale, sandstone and quartzite. On the other hand, dorbank does not have overly flaky aggregates and is non-plastic.

When considering the potential of dorbank crushed in its present condition for a gravel wearing course, low shrinkage factors (SF) are concerning, raising the expectation of the formation of corrugations, ravelling and excessive dustiness. Furthermore, low plastic factors (PF) raise the predicted re-gravelling frequency. Otherwise the aggregate strengths of most dorbanks are sufficient, according to available literature, with Treton values of lower than $65 \%$ for the $16.0 \mathrm{~mm}$ to $19.0 \mathrm{~mm}$ fraction. Concerning the use of crushed dorbank in the prism of sealed roads, dorbank satisfies the maximum Atterberg limits, percentage swell and flakiness requirements of a South African G4 material, but the grading requirements of a G4 gravel are not fully met, and most dorbank samples also do not meet the grading requirements of a $\mathrm{G} 5$ gravel. What is more, the soaked CBR value of the dorbank mixture of samples from the Aggeneys area are too low for consideration as a constituent in the road prism. 
Dorbank is extremely variable in its natural state. It is recommended that:

- The soaked aggregate strength of dorbank should be investigated.

- Proper Venter tests should be conducted for a better understanding of the durability of dorbank (Venter 1980).

- Quantitative XRD analysis of fines should be conducted along with the SEM methods performed in this study.

- The economic viability of using dorbank should be investigated.

- The use of dorbank as an in-situ founding layer should be investigated.

\section{ACKNOWLEDGEMENTS}

We would like to express our gratitude to Dr Frank Netterberg for sharing his wisdom during the course of this research. His insight and expertise greatly assisted this study.

\section{REFERENCES}

Amin, M F M, Huei, C S \& Jamaluddin, T A 2007.

Classification and properties of duricrusts for excavation purposes. Malaysian Journal of Civil Engineering, 19(2): 117-127.

Ampadu, S I K 007. A laboratory investigation into the effect of water content on the CBR of a subgrade soil. In Schanz, T (Ed.). Experimental Unsaturated Soil Mechanics, Springer Proceedings in Physics Series 112, Berlin: Springer, pp 137-144.

ASTM (America Standards for Testing and Materials) 2011. Test Designation 3080: Standard Method for Direct Shear Test of Soils under Consolidated Drained Conditions. West Conshohocken, PA: ASTM International.

Brink, A B A 1985. Engineering Geology of Southern Africa. Volume 4: Post-Gondwana Deposits, 1st ed. Building Publications: Silverton.

Brink, A B A \& Bruin, R M H 2002. Guidelines for soil and rock logging in South Africa, 2nd impression. In Proceedings, Geoterminology Workshop organised by AEG, SAICE and SAIEG, 1990. Midrand: SAICE Geotechnical Division.

COLTO (Committee of Land Transport Officials) 1998. Standard Specifications for Road and Bridge Works for State Road Authorities. Pretoria: COLTO.

CSRA (Committee of State Road Authorities) 1985. Guidelines for Road Construction Materials. Technical Recommendations for Highways (TRH 14). Pretoria: Department of Transport.

CSRA 1986. Standard Methods of Testing Road Construction Materials (TMH1). Technical Methods for Highways (TMH 1). Pretoria: Department of Transport.

CSRA 1990. The Structural Design, Construction and Maintenance of Unpaved Roads. Technical
Recommendations for Highways (TRH 20). Pretoria: Department of Transport.

De Graft-Johnson, J W S 1975. Laterite soils in road construction. Proceedings, 6th Regional Conference for Africa on Soil Mechanics and Foundation Engineering, Durban, pp 89-98.

Ekblad, J 2007. Influence of water on coarse granular road material properties. KTH Royal Institute of Technology. Available at: http://kth.diva-portal. org/smash/record.jsf?pid=diva2:11827.

Ellis, F 2002. Contribution of termites to the formation of hardpans in soils of arid and semi-arid regions of South Africa. Proceedings, 17th World Congress on Soil Science, August 2002, Bangkok, Thailand, Volume 2, Symposium 20, p 791.

Ellis, F \& Schloms, B H A 1981. A note on the dorbanks (duripans) of South Africa. In Van Zinderen-Bakker, E (Ed). Paleoecology of Africa and the Surrounding Islands. Amsterdam: Balkema, pp 149-158.

Fannin, R J, Eliadorani, A \& Wilkinson, J M T 2005. Shear strength of cohesionless soils at low stress. Géotechnique, 55(6): 467-478.

Francis, M L, Fey, M V, Prinsloo, H P et al. 2007. Soils of Namaqualand: Compensations for aridity. Journal of Arid Environments, 70(4): 588-603.

Francis, M L, Ellis F, Lambrechts J J N et al 2013. A micromorphological view through a Namaqualand termitaria (Heuweltjie, a Mima-like mound). Catena, 100: 57-73.

Frey, M 2010. Soils of South Africa 1st ed. Cape Town: Cambridge University Press.

Gregory, G H \& Cross, S A 2007. Correlation of California Bearing Ratio with shear strength parameters. Transportation Research Record, 1989: 148-153.

Ismael, N F \& Al-Sanad, H 1986. Uplift capacity of bored piles in calcareous soils. Journal of Geotechnical Engineering, 112(10): 928-940.

Ismael, N F \& Ahmad, A H N 1990. Bearing capacity of footings on calcareous sands. Soils and Foundations, 30(3): 81-90.

IUSS (International Union of Soil Sciences) 2006. World Reference Base for Soil Resources. World Soil Resources Report No. 103. Rome: IUSS.

McNally, G H 1995. Engineering characteristics and uses of duricrusts in Australia. Australian Journal of Earth Sciences, 42(6): 535-547.

Meyerhof, G G 1963. Some recent research in the bearing capacity of foundations. Canadian Geotechnical Journal, 1(1): 16-26.

Mishra, D, Tutumluer, E \& Butt, A 2010. Quantifying effects of particle shape and type and amount of fines on unbound aggregate performance through controlled gradation. Transportation Research Record, 2167: 61-71. Available at: http:// trrjournalonline.trb.org/doi/10.3141/2167-07.

Mshali, M R \& Visser, A T 2012. Influence of mica on unconfined compressive strength of cement-treated weathered granite gravel. Journal of the South African Institution of Civil Engineering, 54(2): 71-77.
Netterberg, F 1967. Some roadmaking properties of South African calcretes. Proceedings, 4th Regional Conference for Africa on Soil Mechanics and Foundation Engineering, Cape Town, pp 77-81.

Netterberg, F 1969. The interpretation of some basic calcrete types. The South African Archaeological Society Bulletin, 24(95): 117-122.

Netterberg, F 1971. Calcrete in road construction. Research Report 286, Pretoria: National Institute for Road Research, CSIR.

Netterberg, F 1980. Geology of southern African calcretes: 1 . Terminology, description, macrofeatures, and classification. Transactions of the Geological Society of South Africa, 83: 255-283.

Netterberg, F 1982. Geotechnical properties and behaviour of calcretes in South and South West Africa. In Geotechnical Properties, Behaviour and Performance of Calcereous Soils. ASTM Special Publication No 777. West Conshohocken, PA: ASTM, pp 269-309.

Netterberg, F \& Paige-Green, P 1998. Wearing courses for unpaved roads in southern Africa: A review. Proceedings, 7th Annual Transportation Convention, July 1998, Pretoria.

Nouguier-Lehon, C, Cambou, B \& Vincens, E 2003. Influence of particle shape and angularity on the behaviour of granular materials: A numerical analysis. International Journal for Numerical and Analytical Methods in Geomechanics, 27(14): 1207-1226.

Paige-Green, P 1989. The influence of geotechnical properties on the performance of gravel wearing course materials. PhD thesis, University of Pretoria.

Paige-Green, P 2003. The geology and petrology of road construction materials revisited. Proceedings, 13th ARCSMGE Conference, December 2003, Marrakech, Morocco, pp 1-7.

Paige-Green, P 2007. Improved material specifications for unsealed roads. Quarterly Journal of Engineering Geology and Hydrogeology, 40: 175-179.

Paige-Green, P \& Bam, A 1995. The hardness of gravel as an indicator of performance of in unpaved roads. ATC Research Forum, Pretoria, Vol 5, 140-154.

Räisänen, M \& Mertamo, M 2004. An evaluation of the procedure and results of laboratory crushing in quality assessment of rock aggregate raw materials. Bulletin of Engineering Geology and the Environment, 63(1): 33-39.

Razouki, S S \& Bushra, M S 2016. Frequency effect of cyclic soaking and drying on the resilient modulus of gypsum-rich roadbed sand. Transportation Geotechnics, 7: 13-20.

Sanchez-Leal, F J 2002. Interpretation of CBR test results under the shear-strength concept of unsaturated soil mechanics. Proceedings, 3rd International Conference on Unsaturated Soils (USAT), 10-13 March 2002, Recife, Brazil, pp 663-668.

SANRAL (South African National Roads Agency) 2014 Construction equipment and method guidelines, 
Chapter 12. In South African Pavement Engineering Manual, 2nd ed. Pretoria: SANRAL.

Savage, P F 2014. CBR accuracy in question. Proceedings, 33rd Southern African Transport Convention, 7-10 July 2014, Pretoria, pp 500-508.

Singh, B \& Gilkes, R J 1993. The recognition of amorphous silica in indurated soil profiles. Clay Minerals, 28(3): 461-474.

SSSSA (Soil Science Society of South Africa) Non-Affiliated Soil Analysis Work Committee 1990. Handbook of standard soil testing methods for advisory purposes. Pretoria: SSSSA, p 160
Tutumluer, E H, Huang, Y, Hashash \& Ghaboussi, J 2006. Aggregate shape effects on ballast tamping and railroad track lateral stability. Proceedings, AREMA Annual Conference, 17-20 September 2006, Louisville, KY, pp 1-23.

Van Wyk, P R 2013. Rock mechanics for construction of the gravimeter vault at the Matjiesfontein Space Geodesy and Earth Observation Observatory. MEng Dissertation, University of Stellenbosch.

Venter, J 1980. The engineering properties and road building characteristics of mudrocks, with special reference to South Africa. DEng Thesis, University of Pretoria.
Watts, N L1980. Quaternary pedogenic calcretes from the Kalahari (southern Africa): mineralogy, genesis and diagenesis. Sedimentology, 27(6): 661-686.

Weinert, H H 1980. The Natural Road Construction Materials of Southern Africa. Cape Town: H\&R Academica.

Zivica, V \& Bajza, A 2001. Acidic attack of cementbased materials: A review. Part 1. Principle of acidic attack. Construction and Building Materials, 15(8): 331-340. 